\title{
THE RELATIONSHIP BETWEEN ORTHODONTIC TREATMENT AND PERIODONTAL HEALTH
}

\author{
HIMAWAN HALIM*
}

Department of Orthodontic, Trisakti University, West Jakarta, Indonesia. Email: himawan@trisakti.ac.id

Received: 11 March 2020, Revised and Accepted: 18 April 2020

\begin{abstract}
There is a need to consider numerous factors in orthodontic treatment, including diagnosis before and during treatment. This activity is necessary to prevent the incidence of periodontal abnormalities or the aggravation of existing ones, which is possibly overcome through orthodontic treatment under certain circumstances.
\end{abstract}

Keywords: Orthodontic treatment, Periodontal health, Relationship.

(C) 2020 The Authors. Published by Innovare Academic Sciences Pvt Ltd. This is an open access article under the CC BY license (http://creativecommons. org/licenses/by/4. 0/) DOI: http://dx.doi.org/10.22159/ajpcr.2020.v13i6.37405

\section{INTRODUCTION}

The purpose of orthodontic treatment is to ensure good positioning and connection of the teeth and jaws. This science has been progressed very rapidly in terms of material and treatment techniques to enable the procedure on children, adolescents, and adults. However, an important challenge to be considered is the periodontal problem experienced by the patient, both before and during treatment. This is because orthodontic appliances, especially the fixed type, tend to inhibit the ability to properly perform oral hygiene, subsequently can cause qualitative and quantitative changes in the accumulation of plaque, while the use of this tool causes periodontal abnormalities [1-6]. Patients undergoing orthodontic treatment have tendency for increased plaque accumulation. The presence of plaque in the initiation and progression and recurrence of periodontal disease is a very important factor. Adequate plaque control on reduced periodontal support is safe to move teeth [7-10].

Data from the Ministry of Health, Republic of Indonesia in 1987 showed a high prevalence of periodontal disease at $62.36 \%$ for 8 -year-old individuals, $81.91 \%$ and $87.64 \%$ for 14 and 35 years old, respectively [2]. Meanwhile, the presence of periodontal problems before treatment leads to a worse outcome, despite the statement by Brown and Ericson, which indicates the requisition of orthodontic treatment to overcome certain periodontal problems [6,11]. In addition, the movement of teeth during treatment involves a network of dental support, hence the periodontal tissue health must be considered in-depth before and during the process [12]. During treatment, orthodontists are responsible for monitoring the oral hygiene status of individual patients. In adult patients, the condition is more complex due to the presence of restorations, which increase plaque accumulation and the risk of deterioration of periodontal diseases [13-16].

The periodontal tissue health can be accessed using the following criteria: Bleeding, the type of soft tissue, inflammation, bone damage, and various other factors. This paper discusses the importance of the link between periodontal problems and orthodontic treatment.

\section{LITERATURE REVIEW}

The main factor to consider before and during treatment includes the presence of gingival sensitivity which occurs in the form of bleeding. In addition, the presence of others, including soft tissue type, gingival response to tooth eruption, mucogingival deformity, frenum, breathing through the mouth, gingival hyperplasia, and Dilantin hyperplasia ought to also be given attention $[1,17,18]$. The most minor periodontal problem is inflammation of the gingiva, also known as gingivitis, although the occurrence of gingival bleeding during the period of mild probing the periodontal pocket is the easiest detection method. Furthermore, the resulting tissue damage causes the gingiva to appear erythematous and edematous, as sensitive conditions necessitate the cleaning of calculus or scaling before treatment $[1,17]$.

Gingival and periodontal disease is influenced by various factors, including self-immunity, social and behavioral characteristics, which affect the value of beliefs and adherence, respectively, disturbed systemic resistance (for example, immunodeficient human status), genetic predisposition, and finally both quantitative and qualitative bacterial biofilms (dental plaque) composition at the gingival margin [19-21]. Meanwhile, advanced disorders and bone damage is accompanied by the oscillation of teeth, which requires supplementary treatment by a periodontist. It is necessary for the dentist to consider mild and severe periodontal tissue abnormalities, required for therapy $[9,22]$.

In orthodontic treatment, teeth with thin and sensitive soft tissue are more prone to gingival recession than normal and thick. Hence, the oral hygiene index of patients with thin periodontal ought to be identified before the placement of the orthodontic device placement, where bonding is preferred to banding $[12,23]$. In addition, gingivitis often appears on instances when permanent teeth erupt and are also known as Eruptive Gingivitis, which is known as a normal condition, while the presence over the contours of the tooth neck eases the accumulation of sub-gingival bacteria. There is no research affiliating erupted teeth with the incidence of gingivitis, although this manifestation has been implicated as a sign of failure to clean plaque present in the mouth. This must be properly controlled if this condition is identified in patients treated orthodontically.

The lower central incisors in normal tooth eruption are often located more labially than the lateral incisors. These differences in the position of the labiolingual direction cause variation between the gingival picture of the tooth and those on the side gingival, where the tissue is thinner. This also generates thin connective tissue between the gingival epithelium and the periosteum, making it difficult to know the potential of keratinization from the epithelium [24-26].

The labial frenulum is often associated with inadequate attached gingival width, especially in the upper jaw, which is possibly overcome by surgical techniques, due to the inability for orthodontic treatment to increase the width of attached gingiva. Many researchers have demonstrated the existence of a relationship between the median diastema and superior labial frenulum, which specifically prevents 
the migration of central incisors to the mesial [27-29]. Some previous investigations proposed the total removal of frenulum (frenectomy) before the conduction of orthodontic treatment, although a new opinion suggests the removal of frenulum done after completing the closing space treatment, to ensure that space is closed. This occurs because the removal has been associated with the incidence of scarring, which prevents the closing by orthodontic treatment procedure. Subsequently, the frenulum is expected to shrink [29].

To avoid diagnosing an abnormal frenulum is possibly avoided by always remember the occurrence of a physiological space between the growth of permanent central incisors and permanent canines. This is also another reason to remove the frenulum after completing the orthodontic treatment, to confirm the frenulum attachment responsible for the median diastema, which is carried out by: (1) Blush test, which involves pulling the upper lip in the frenulum area and observing the existence of a pale area in the palatal region, resulting from the pull; (2) The creation of photo roentgen, in attempts to recognize the state of the median septum [28].

Patients with a habit of breathing through the mouth are often faced with malocclusion and periodontal problems. Therefore, the effect of dryness in sensitive patients leads to the enlargement of gingiva and erythematous, especially in the anterior region of the lower and upper jaw. However, the lips of patients that breathe through the mouth are usually dry and cracked, while withdrawal with an orthodontic device in the anterior area is capable of helping sufferers obtain better "lip seal." Before this procedure, it is important to control the patient's oral hygiene, alongside the cleaning of calculus and root planning, in attempts to relieve inflammation [30-32].

The appliance use leads to the occurrence of gingival enlargement, which is generally temporary and self-improve after removal, subsequently providing satisfactory results after cleaning the plaque and calculus. According to Kaswiner (1981) enlargement usually reduces greatly within $48 \mathrm{~h}$ of tool removal, which makes it better to correct the gingiva shape by performing a surgical procedure [33].

It is also important that dentists pay attention to sufferers of gingival enlargement caused using Dilantin drug aimed at achieving tight and regular control of plaque and calculus. Therefore, it is necessary to conduct gingivectomy before treatment, as surgical procedures are usually required to obtain an anatomic crown and allow for teeth eruption followed by the fixing of orthodontic appliances within 10 days [34-36]. Meanwhile, oral prophylaxis ought to be conducted once a week on patients using drugs (Dilantin) to prevent tissue regrowth. Usually, the teeth movement rapidly occurs in the beginning of the healing process; therefore, all efforts must be made to ensure a quick procedure. Furthermore, instances where the surgical procedure performed on fibrous tissue has to be repeated several times lead to orthodontic treatment failure [34,37-39].

Beside the use of drugs, gingival enlargement is often associated with uncontrolled diabetes, inadequate nutrition, and systemic hormonal stimulation during puberty and pregnancy $[40,41]$. Meanwhile, the features of enlargement, edema, softness, and soft to the touch, which bleeds easily on minor trauma, are indicative of acute monocytes, lymphocytes, and myelocytic leukemia [23,33], while thrombocytopenia and thrombocytopathy cause enlargement and bleeding. This condition tends to worsen on instances where oral hygiene is not maintained, subsequently increasing plaque accumulation. Furthermore, some syndrome has been affiliated with gingival health, including Rutherford's, Ramon's, and Laband's, which is worsened by fixed plaque-causing orthodontic appliances [42-46]. In addition, it is also expected that doctors involved in the treatment period are always aware of the syndrome consequences.

Periodontal problems ought to be considered before or during the orthodontic treatment period, alongside preventing the occurrence of periodontal abnormalities and exacerbating existing ones. According to Vanarsdall, 1981, therapy is also used to determine the possibility of overcoming existing periodontal problems, including (1) Deficiency in "lip seal," resulting from malocclusion; (2) "Molar uprighting;" (3) improvement of severe teeth malocclusion in relation to alveolar bone in cases of dehiscence; (4) anterior functional crossbite with "jiggling occlusion;" (5) correction of malpositioned teeth, in relation to Dilantin gingivitis or gingival fibromatosis; (6) anterior teeth extrusion with advanced periodontitis, accompanied by pathological migration; (7) esthetic and restorative reasons; (8) bite open with contact only on the last molar; and (9) tooth eruption with subcrestal factors or "infra bony pocket" [12].

\section{DISCUSSION}

Recently, there has been an upsurge in the adult patient demand for orthodontic treatment despite the data from the Ministry of Health's survey (1987), which shows an increase in the prevalence of the periodontal disease in Indonesia with increasing age [1]. These abnormalities are often faced by dentists before orthodontic treatment in adults, subsequently necessitating periodontics involvement.

Although bacteria have been identified as the main cause of gingivitis and periodontitis, animal experiments have proven the possibility of a recession in gingiva and bone damage after treatment. In addition, patients with periodontal abnormalities and orthodontic pressure are able to accelerate the pending damage $[45,46]$, which according to Kaswiner (1981) occurs rapidly in all treated patients [33]. This occurs at a degree dependent on individual oral hygiene, as a very good state is devoid of tissue damage.

In many cases, missing teeth were identified during orthodontic treatment, as a result of the inability to control activities related to periodontal abnormalities before the procedure. Therefore, individuals with severe cases need to undergo periodontics treatment 3-4 months in advance [42,45]. The purpose of periodontics treatment is to: (1) Repair damaged bones and strengthens the teeth position; (2) heal or control the disease severity, and stabilize the process of existing abnormalities. However, the inability to meet up the above conditions indicates the propensity for failure in treatment.

It is important to pay attention to the following during orthodontic treatment in patients with periodontal abnormalities, including (1) type of orthodontic appliance to be used; (2) depth of gum pocket; (3) teeth position in the supporting tissue; (4) patient motivation and skills in maintaining oral health; (5) bifurcation as well as trifurcation conditions, and (6) hypertrophic tissue conditions.

Orthodontic treatment is performed on children or young adults, faced with periodontal problems, including gingivitis caused by plaque accumulation. This is congruent with the results of research by Sugiarto (1983) on individuals aged 7-14 years, at an elementary school, and $100 \%$ prevalence of gingivitis was established [46-49]. Therefore, it is important that patients learn how to properly control plaque and clean calculus a few days prior, in preparation for orthodontic treatment. This is not recommended when the device is to be installed because the gingiva is highly sensitive with remnants of bleeding that possibly interferes with the attachment of the adhesive material on the tooth surface $[33,48-50]$.

The use of fixed orthodontic appliances causes plaque retention and soft tissue irritation to occur easily. These surface bands associated with gingiva tend to change supragingival plaque into subgingival as the cleaning process becomes more difficult [51]. Therefore, the occurrence of periodontal abnormalities is highly dependent on oral hygiene maintenance. This is possibly performed using a special toothbrush to mechanically cleaning the plaque while the dentist plays a role as the main motivator at each patient visit through the period of active treatment. 
Therefore, a close and inseparable link was established between orthodontics and periodontology in treating patients using orthodontics.

\section{CONCLUSION}

It is important to carefully consider and always remember the periodontal problems of patients before and during orthodontic treatment, which makes the process successful. However, the process conduction in certain circumstances possibly overcomes periodontal abnormalities.

This paper attempts to describe all the positive and negative effects associated with using orthodontic appliances on gingival tissue. Therefore, it was confirmed that fixed orthodontic appliance causes undesirable changes, including the formation of plaque storage areas, ecosystem changes, and shifts from normal flora to microbes characterized as periodontopathogens, gingival inflammation, gingival irreversible hyperplasia, permanent loss of periodontal attachment, and gingival dehiscence (recession).

This effect is controlled through proper oral hygiene measures, as a failure of adhering to regimen leads to the initiation of damaging periodontal disease through violations of the natural protective barrier. Furthermore, a close collaboration is needed between orthodontics and periodontology in preparing patients, especially in handling adult cases.

\section{AUTHORS' CONTRIBUTIONS}

The author has written the manuscripts.

\section{CONFLICTS OF INTEREST}

The author declares that he does not have any conflicts of interest.

\section{FUNDING}

No funding was provided for this study.

\section{REFERENCES}

1. Alexander RG. The Alexander Dicipline. Glendora: Ormco.Co.; 1986.

2. Badan Penelitian dan Pengembangan Kesehatan. Riset Kesehatan Dasar (RISKESDAS) 2018. Jakarta: Badan Penelitian dan Pengembangan Kesehatan; 2018. p. 1-628

3. Klukowka M, BaderA, Erbe C, Bellamy P, White DJ, Anastasia MK, et al. Plaque levels of patients with fixed orthodontic appliances measured by digital plaque image analysis. Am J Orthod Dentofacial Orthop 2011;139:463-70.

4. Balenseifen JW, Madonia JV. Study of dental plaque in orthodontic patients. J Dent Res 1970;49:320-4.

5. Huser MC, Baehni PC, Lang R. Effects of orthodontic bands on microbiologic and clinical parameters. Am J Orthod Dentofacial Orthop 1990;97:213-8.

6. Brown IS. The effect of orthodontic therapy on certain types of periodontal deffects. i-clinical findings. J Periodontal 1973;44:742-56.

7. Boyd RL, Leggot PJ, Quinn RS, Eakle WS, Chambers D. Periodontal implications of orthodontic treatment in adults with reduced or normal periodontal tissues versus those of adolescents. Am J Orthod Dentofacial Orthop 1989:96:191-9.

8. Ong MA, Wang HL, Smith FN. Interrelationship between periodontics and adult orthodontics. J Clin Periodontol 1998;25:271-7.

9. Nattrass C, Sandy JR. Adult orthodontics-a review. Br J Orthod 1995;22:331-7.

10. Matuliene G, Pjetursson BE, Salvi GE, Schmidlin K, Brägger U, Zwahlen $\mathrm{M}$, et al. Influence of residual pockets on progression of periodontitis and tooth loss: Results after 11 years of maintenance. $\mathrm{J}$ Clin Periodontol 2008;35:685-95.

11. Ericsson I, Thilander B, Okomoto H. The effect of orthodontic tilting movements on the periodontal tissues of infected and non infected dentiton in digs. J Clin Perio 1977:4:278-93.

12. Vanarsdall RL. Periodontal problems associated with orthodontic treatment. Am Acad Periodontics 1981;13:154-7.

13. Wennstrom JL, Stokland BL, Nyman S, Thilander B. Periodontal tissue response to orthodontic movement of teeth with infrabony packets. Am J Orthod Dentofacial Orthop 1993;103:313-9.

14. Krishnan V, Davidovitch Z. Cellular, molecular and tissue level reactions to orthodontic force. Am J Orthod Dentofacial Orthop 2006;129:469.1-32.

15. Nyman S, Lindhe J, Rosling B. Periodontal surgery i plaque-infected dentitions. J Clin Periodontol 1977;4:240-9.

16. Rosling B, Nyman S, Lindhe J. The effect of systematic plaque control on bone regenaration in infrabony pockets. J Clin Periodontol $1976 ; 3: 38-53$.

17. Nanci A, Bosshardt DD. Structure of periodontal tissues in health and disease. Periodontal 2000 2006:40:11-28.

18. Muller HP, Eger T. Gingival phenotypes in young male adults. J Clin Periodontol 1997:24:65-71.

19. Ashley FP, Usiskin LA, Wilson RF, Wagaiyu E. The relationship between irregularity of the incisor teeth, plaque, and gingivitis: A study in a group of school children aged 11-14 years. Eur J Orthod 1998:20:65-72.

20. Davies TM, Shaw WC, Worthington HV, Addy M, Dummer P, Kingdon A. The effect of orthodontic treatment on plaque and gingivitis. Am J Orthod Dentofacial Orthop 1991;99:155-61

21. Zambon JJ. Periodontal diseases: Microbial factors. Ann Periodontol 1996;1:879-925.

22. Wennstrom J, Lindhe J. Plaque-induced gingival inlammation in the absence of attached gingiva in dogs. J Clin Periodontol 1983;10:266-76.

23. Serino G, Wennstrom JL, Lindhe J, Eneroth L. The prevalance and distribution of gingival recession in subjects with a high standard of oral hygiene. J Clin Periodontol 1999;70:30-43.

24. Olsson M, Lindhe J, Marinello CP. On the relationship between crown form and clinical features of the gingiva in adolescents. J Clin Periodontol 1993;20:570-7.

25. Rupprecht RD, Horning GM, Nicoll BK, Cohen ME. Prevalence of dehiscenses and fenestration in modern American skulls. J Periodontol 2001;72:722-9.

26. Elliott JR, Bowers GM. Alveolar dehiscence and fenestrations. Periodontics 1963;1:245-8

27. Olsson M, Lindhe J. Periodontal characteristics in individuals with varying form of the upper central incisors. J Clin Periodontol 1991;18:78-82.

28. Huang WJ, Creath CJ. The midline diastema: A review on its etiology and treatment. Pediatr Dent 1995;17:171-9.

29. Dibart S, Karima M. Dibart Serge, Mamdouth K. Practical periodontal plastic surgery. In: Labial Frenectomy Alone or in Combination with a Free Gingival Autograft. Germany: Blackwell Munksgaard;2017.

30. Phulari BS, editor. Orthodontics: Principles and Practice. New Delhi: Jaypee Brothers, Medical Publishers; 2011.

31. Bresolin D, Shapiro PA, Shapiro GG, Chapko MK, Dassel S. Mouthbreathing in allergic children, its relationship to dentofacial development. Am J Orthod Dentofacial Orthop 1983;83:334-40.

32. Jacobson L. Mouthbreathing and gingivitis. J Periodontal Res 1973;8:269-77.

33. Kaswiner LM. Hard and soft tissue damage accompaniying orthodontic therapy. Clin Prevent Dent 1981;3:9-11.

34. Handelman CS. The anterior alveolus: Its importance in limiting orthodontic treatment and its influence on the occurance of iatrogenic sequelae. Angle Orthod 1996;66:95-109.

35. Guidelines for epidemiologic studies on epilepsy. Comission on epidemiology and prognosis, international league against epilepsy. Epilepsia 1993;34:592-6

36. McLeod DE, Stoeckel D, Contreras J, Reyes E. Severe postpartum gingival enlargement. J Periodontol 2009;80:1365-9.

37. Katz J, Givol N, Chaushu G, Taicher S, Shemer J. Vigabatrin-induced gingival overgrowth. J Clin Periodontol 1997;24:180-2.

38. Seymour RA, Ellis JS, Thomason JM. Risk factors for drug-induced gingival overgrowth. J Clin Periodontol 2000;27:217-23.

39. Marshall RI, Bartold PM. A clinical review of drug-induced gingival overgrowths. Aust Dent J 1999;44:219-32.

40. Martorelli SB, Andrade FB, Martorelli FO, Marinho EV, Melo JF, Silva AC. Atypical gingival overgrowth phenytoin-induced a case report. Int J Dent 2008;7:69-72.

41. Bobetsis VA, Barros SP, Offenbacher S. Exploring the relationship betweenperiodontal disease and pregnancy complications. J Am Dent Assoc 2006; 137:7-12.

42. Graber TM, Swain BF. Orthodontics Current Principles and Techniques. St Louis,CV Mosby Co.; 1985.

43. Albandar JM, Kingman A. Gingival recession, gingival bleeding and dental calculus in adults 30 years of age and older in the United States, 
1988-1994. J Clin Periodontol 1999;70:30-43.

44. Gorman WJ. Prevalence and etiology of gingival recession. J Clin Periodotol 1967;38:316-22.

45. Hancock EB. Determination of periodontal diseases activity. J Periodontol 1981;52:492-7.

46. Proffit WR. Contemporary Orthodontic. $6^{\text {th }}$ ed. St. Louis: CV Mosby Co.; 2019.

47. Sugianrto RH. Prevalensi, Keparahan dan faktor penyebab Gingivitis Pada anak SD Yon Angmor Senen Jakarta. Kumpulan Naskah Ilmiah Kursus Penyegar dan Penambah Ilmu Kedokteran Gigi VI; 1983. p. 1-13.

48. Carranza FA, Rapley JW, Haake SK. Gingival inflammation. In: Newman MG, Takei HH, Carranza FA, editors. Clinical Periodontology. $9^{\text {th }}$ ed. Philadelphia, PA: Saunders; 2003.

49. Yusrawati Y, Delmi S, Desmawati D. The correlation between estradiol levels with telemere length based on history of using hormonal contraceptive in premenopausal women. Asian J Pharm Clin Res 2018;11:336-9.

50. Radha M, Suganya J, Sharanya M, Astral F, Urja S. In silico metabolic pathway analysis of Treponema pallidum subs. pallidum nichols for potential drug targets. Asian J Pharm Clin Res 2017;10:261-4.

51. Melsen B, Allais D. Factors of importance for the development of dehiscences during labial movement of mandibular incisors: A retrospective study of adult orthodontic patients. Am J Orthod Dentofacial Orthop 2005;127:552-61 